\title{
Clinical Evaluation of the Efficacy of Gomutra Aasava in Shvitra Vis-A-Vis Vitiligo.
}

\author{
Raman S. Belge ${ }^{1}$, Archana R. Belge ${ }^{2}$ \\ ${ }^{I}$ Dept. of Rasshastra \& Bhaishajya Kalpana, Shri Saptshrungi Ayurved College, Nashik, Maharashtra, India. \\ ${ }^{2}$ Dept. of Swasthavritta, Shri Saptshrungi Ayurved College, Nashik, Maharashtra, India.
}

\begin{abstract}
Vitiligo is an acquired depigmenting skin condition that results from the destruction of melanocytes. It is a progressive, idiopathic pigmentation skin disorder, characterized by hypopigmented patches. The Vedic texts have even mentioned the term 'Kilasa' or Shvitra to describe hypopigmented patches. According to Ayurveda, Shvitra is caused by improper diet and behavioral factors. Certain other factors like Daivakrita nidana, beejadushti nidana and nidana-arthakar vyadhis are known to induce Shvitra. Many Ayurvedic medicines are known ro regenerate melanocytes among which Gomutra Aasava is the one. The present paper deals with the clinical evaluation of the efficacy of Gomutra Aasava in Shvitra.
\end{abstract}

Keywords: Shvitra, Vitiligo, Gomutra, Aasava.

\section{Introduction:}

Vitiligo is a pigmentation disorder having multifactorial origin eg. Genetic-endocrine-nutritional factors; chemical and pharmalogic agents, physical agents. A milky white or ivory white depigmented patch, generally lined by a rim of hyperpigmentation appear on scalp, retro-auricular folds, upper eye-lids, lips, fingertips, palms, nipples, waist, scrotum, glans, legs, toe-tips and soles. Teenagers are normally affected. Etiology of vitiligo can be summarised as follows ${ }^{1,2,3}$ :-

a) Neural Concept :- Peripheral nerve-endings secrete cytotoxic substances viz. melantonin which damages the melaocytes.

b) Auto-Immune Mechanism :- Antibodies against melanin have been isolated from the serum of vitiligo patients. Hence, vitiligo is an auto-immune disorder.

c) Melanocyte Exhaustion Theory :- Due to the continuous strain of producing melanin, the melanocytes get exhausted resulting into vitiligo.

Amonget various theories, Auto-Immune concept for disseminated Vitiligo and neural concept for segmental vitiligo are widely accepted.Gomutra Aasava contains Shunthi, Maricha, Pippali, Chitraka, Madhu and Gomutra ${ }^{4,5,6}$.

Gomutra asava being Aampachak reduces dhatu-samata. Due to Strotomukha-Vishodhana the Vimargagamit doshas are placed back in their Original Sthanas. Being Kapha-Vata shamak, it balances the vitiated Kapha dosha.

Gomutra asava stimulates liver and spleen; thereby regulating the function of Pachaka Pitta, Ranjakapitta and Bhrajakapitta. It also acts as a Raktaprasadana dravya.

Being Yogavahi (catalyst) it acts fastly, hence Gomutra Asava was selected to evaluate its role in treating Shvitra-vis-a-vis vitiligo.

\section{Aims and Objectives:}

1) To study the etiopathogenesis of Shvitra vis-a-vis Vitiligo in detail.

2) To evaluate the efficacy of Gomutra Asava in pigment regeneration in vitiligo.

\section{Materials and Methods:}

This was a randomized clinical trial conducted in experimental group at Dept. of Kayachikitsa of Shri Ayurved Mahavidyalaya, Nagpur ${ }^{7}$.

A total of 46 uncomplicated symptomatically diagnosed cases of shvitra were studied during this research work.

\section{InclusionCriteria:}

Diagnosed cases of uncomplicated vitiligo, either segmental or generalized, of both the sexes in the age group of 8 to 70 years were registered. 


\section{Exclusion Criteria:}

1) Vitiligo associated with malignant melanoma, albinism \& other skin-diseases.

2) Pregnancy (Chitraka causes uterine contractions, hence avoided in patients with Pregnancy)

3) PNC \& lactating mother (effects not fully studied in infants)

\section{Assessment Criteria:}

a) Surface area of Hypopigmented patches was measured with the help of Trace-Paper and Graph Paper.

b) Colour-Change in Patches -

International Protocol for Grading of Repigmentation :-

Grade 1 - Diffuse lightening usually seen at margins (tan colour)

Grade 2 - Perifollicular repigmentation

Grade 3 - Spreading of Perifollicular repigmentation

Grade 4 - Coalescing pigmentation with areas of depigmentation in between.

Grade 5 - Confluent repigmentation with remnant islets of depigmentation in between.

Grade 6 - Complete repigmentation.

Note :- These grades should be applied to a single predetermined representative macule on various body parts.

c) Colour \& Patches :-Shweta (Depigmented/White), Mishra (Trichrome), Tamra(Coppery/Hypopigmented), Rakta (Red/Pink).

d) Colour of Hair in a depigmented Patch: Total loss of Hair; white (Shuklavarna), whitish (ashuklavarna), black.

e) Burning and Itching in the Patches were also noted as,,,++++++++++ according to their intensity.

f) Relief (Upashaya) was assessed by noting changes in the surface area of Patches -

No relief - $\quad 0 \%$

Good relief - $1-25 \%$

Better relief - $\quad 26-50 \%$

Best relief - $\quad 51-75 \%$

Excellent relief - 76-99\%

Total relief - $\quad 100 \%$

Duration of Trial :-6 months with monthly follow-ups.

Trial Drug :-

Gomutra Asava - Ingredients.

Gomutra (Cow's Urine) - 100 Ltr.

Chitraka (Plumbago zeylanica) - $960 \mathrm{~g}$.

Shunthi (Zingiber officinale) - $960 \mathrm{~g}$.

Maricha (Piper nigrum) - $960 \mathrm{~g}$.

Pippali (Piper longum) - $960 \mathrm{~g}$.

Madhu (Honey) $-19.230 \mathrm{~kg}$.

All these ingredients were mixed and fermented for 15 days. After having Sandhana-Pariksha, the product was filtered and dispensed to the patients of experimental group.

\section{Gomutra Asava :-}

$\mathrm{pH}$ - Neutral

Alcohol Content - $4 \%-4.5 \%$

Sugars - Reducing type

Alkaoids - Present

Route of Drug Administration - Orally, twice a day after meals with equal volume of water.

Dosage :- 6-12 yr. - $20 \mathrm{ml} / 2$ doses

$13-60$ yr. $-40 \mathrm{ml} / 2$ doses

above 60 yr. - $30 \mathrm{ml} / 2$ doses.

\section{Observation \& Results:}

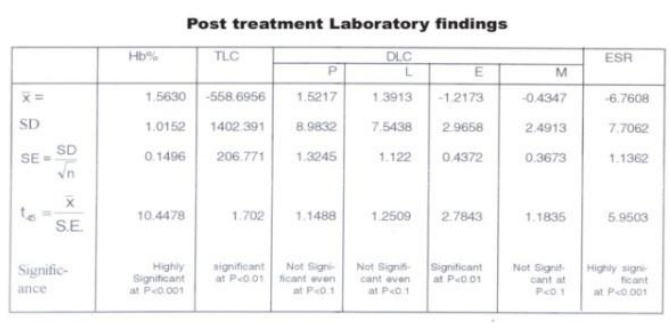



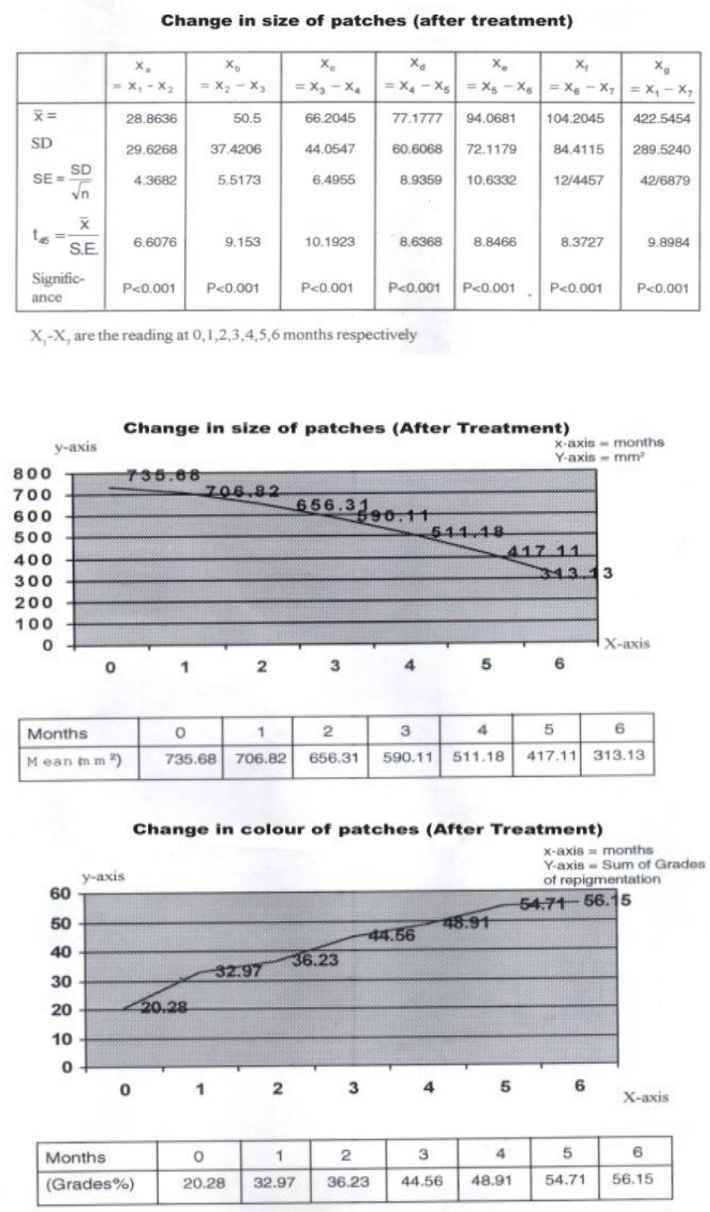

- The youngest patient was a 8 year old male and the oldest patient was a female of 70 years. However in the age-group of 11-20 years occurrence was highest (23.9\%) and in (1-10) yr, group it was lowest $(2.17 \%)$

- Family history was observed in 4 patients $(8.69 \%)$

- Vatapittaja Prakriti (45.65 \%), Kaphapittaja Prakriti (43.48\%) were noted.

- Vitiligo Vulgaris (bilaterally symmetrical patches) observed at bony prominences of arms \& legs; face, neck and axilla $-45.65 \%$

- Changes in size of patch - Mean $\left(\mathrm{mm}^{2}\right)$ at 0 months was $735.68 \mathrm{~mm}^{2}$ After treatment of 6 months mean was $313.13 \mathrm{~mm}^{2}(\mathrm{P}<0.001)$

- Changes in Colour of Patch: - Grades (\%) at 0 months were 20.28 grade \%. After treatment of 6 months, grade $\%$ was $56.15 \%(\mathrm{P}<0.001)$

- Haemoglobin level raised $(\mathrm{P}<0.001)$

- $\quad$ ESR lowered $(\mathrm{P}<0.001)$

TLC (Eosinophils) lowered ( $\mathrm{P}<0.01)$

No significant changes were observed in Polymorphs, Lymphocytes and

Monocytes $(\mathrm{P}>0.01)$

- Leucoderma Patches due to burn - No relief $(0 \%)$

- Family history - Four patients Result \% and relation with vitiligo patients are as follows - $0 \%$ (Sister), 28.75\% (Mother), $61.53 \%$ (Sister), $65.60 \%$ (Sister)

- Allergic leucoderma Patches - Result \% and cause of allergy -Two Patients had allergic leucodermaPatient No. (1) - $89.69 \%$ relief (Metallic wrist watch belt was changed to a rubber belt). Patient No. (2) - $90.00 \%$ (Constract use of a branded lip-stick)

- Duration of Illness :-

Upto 1 yr. - relief $\%$ was $70 \%$ and neural concept for segmental vitiligo......more than 1 yr. - relief $\%$ was $19.44 \%$

- Exposed areas of the body involved and best relief \%

Forearms (100 \%); Wrist joints (31.33 \%); Palms (30.77 \%); Soles (6.8 \%); Face (18.56 \%); Elbow joints $(14.76 \%)$; Neck (11.93\%); Chest/Abdomen (11.92\%); Thighs (19.84\%). 


\section{Discussion:}

Vitiligo is an acquired, progressive, idiopathic depigmenting skin condition. Amongst various theories, Auto-Immune theory for disseminated vitligo and neural concept for segmental vitiligo are widely accepted theories.

According to Ayurvedic texts; lasika, rakta and mamsa are vitiated in shvitra. Excessive use of Kaphaja Ahara and Vihara leads to the obstruction of Strotasas.

Gomutra asava due to its Katurasa, Katuvipaka and Ushnavirya removes the obstruction of strotasas and also normalises the function of Pachakapitta. Ultimately, ranjakapitta and bhrajakapitta. function normally, thereby repigmenting the hypopigmented patches. In short, it acts on liver and spleen (Raktashaya) as can be observed by raised $\mathrm{Hb} \% \mathrm{P}<0.001$; low ESR $\mathrm{P}<0.001$; Low TLC $\mathrm{P}<0.01$; Low Eosinophils $\mathrm{P}<0.01$ and colour change in patches $\mathrm{x}^{2} \mathrm{P}<0.001$.

\section{Conclusion:}

According to Ayurvedic texts, Shvitra is an Krichhrasadhya Vyadhi, having Kaphadushti as a most important factor. Improper diet and behavioural factors precipitate Shvitra. Shvitra can be correlated with vitiligo.

A Clinical trial with oral administration of Gomutra Aasava containing Shunthi, Maricha, Pippali, Chitrak, Madhu and Gomutra proved that the formulation is a safe remedy with significant repigmentation property.

\section{References}

[1]. Braunwald, Karper, et al. Part-7, Section 54, 17 th ed, Vol.1, New York: McGraw Hill; 2008. Harrisons Principles of Internal Medicine; pp. 324-326.

[2]. Jopling \& McDougall, Handbook of Leprosy; $1^{\text {st }}$ ed; Heinemann Publishing Ltd. Oxford:1988; pp. 113.

[3]. D. Murray, Scientific Skin Care; $1^{\text {st }}$ ed. Arlington Books Ltd. London; 1983; pp. 107.

[4]. Vagbhata, Ashtanga Hridayam,Vaidya Lalchanda Shastri, Chikitasasthana, $1^{\text {st }}$ ed, Motilal Banarasidas, 1977. pp. 519.

[5]. Vagbhata, Ashtang Sangraha, Chhangani Govandhan Sharma, Chikitsasthana, $1^{\text {st }}$ ed, Chowkhamba Sanskrit Sansthana, 1979. pp. 617.

[6]. Sushruta, Sushruta Samhita, Shastri Ambikadatta, Chikitsasthana, $1^{\text {st }}$ ed, Chowkhamba Sanskrit Sansthan, 1997. pp. 249.

[7]. Raman Belge; Gomutra Aasav Nirman evam Shvitrarogpar uske Prabhav Ka Aturalayin Adhyayan; M.D.(Ayu.)Thesis; Submitted to Nagpur Univ. Nagpur 2001. 